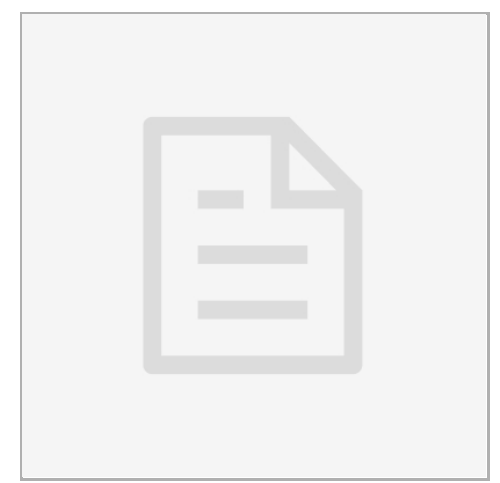

AUG 12, 2020

\title{
(3) Feeding of cats with hyper-immune eggs: an oral immunization protocol
}

\author{
Angel A Justiz-Vaillant ${ }^{1}$ \\ ${ }^{1}$ University of the West Indies St. Augustine \\ University of the West Indies \\ angel.vaillant@sta.uwi.edu
}

Angel A Justiz-Vaillant

University of the West Indies St. Augustine

\section{open ठaccess}

\section{DOI:}

dx.doi.org/10.17504/protocol s.io.bjnnkmde

Protocol Citation: Angel A Justiz-Vaillant 2020. Feeding of cats with hyper-immune eggs: an oral immunization protocol. protocols.io

https://dx.doi.org/10.17504/p rotocols.io.bjnnkmde

License: This is an open access protocol distributed under the terms of the Creative Commons Attribution License, which permits unrestricted use, distribution, and reproduction in any medium, provided the original author and source are credited

Protocol status: Working We use this protocol and it's working

Created: Aug 12, 2020

Last Modified: Aug 12, 2020

PROTOCOL integer ID: 40366

1 The anti-gp120 positive eggs (hyper-immune eggs) are fed to 3 out of 5 cats. Three (3) adult cats, 2-3 years old ( 1 male and 4 female). A sixth cat that was a part of the control group died during the experiment. 
2 Each cat receives on average of 2 eggs diluted in 5 volumes of soya milk weekly for 10 weeks.

3 Of the 5 cats used in the study, 3 are fed hyper-immune eggs (anti-gp120), while the remaining 2 cats are fed eggs from non-immunized chickens.

4 And these two cats that are fed with eggs from non immunized chickens are use as controls.

$5 \quad$ Blood samples $(2 \mathrm{ml})$ are collected from each cat, after completion of the feeding.

6 They are all tested for anti-HIV antibodies by an indirect HIV ELISA. 